\title{
Chronic obstructive pulmonary disease and malnutrition: why are we not winning this battle?"
}

\author{
IVONE MARTINS FERREIRA ${ }^{1}$ (TE SBPT)
}

\begin{abstract}
Objectives: To review the mechanisms involved in the origin of malnutrition in patients with chronic obstructive pulmonary disease (COPD), and to make a systematic review of randomized controlled studies, to clarify the contribution of nutritional supplementation in patients with stable COPD. Method: A systematic review of articles published in the field of nutrition, in any language and from several sources, including Medline, Embase, Cinahl, and the Cochrane Registry on COPD, as well as studies presented at congresses in the US and Europe. Results: Studies on nutritional supplementation for more than two weeks showed a very small effect, not reaching statistical significance. A linear regression study found that old age, relative anorexia, and high inflammatory response are associated with non-response to nutritional therapy. Conclusion: Currently, there is no evidence that nutritional supplementation is truly effective in patients with COPD. Factors associated with non-response suggest a relationship with the degree of inflammation, including high TNF-alpha levels. Measuring inflammation markers may be useful to determine prognosis and adequate therapy. Treatment with anti-inflammatory cytokines or cytokine inhibitors seems promising for the future. (J Pneumol 2003;29(2):107-15)
\end{abstract}

Key words - Chronic obstructive pulmonary disease. Eating disorders. Inflammation. Food supplementation.

Acronyms and abbreviations used in this article

COPD - Chronic obstructive pulmonary disease

TNF-alpha - Tumor necrosis factor alpha

DALY - Disability adjusted life year

BMI - Body mass index

$\mathrm{FEV}_{1}$ - Forced expiration volume in the first second
DEXA - Dual X-ray absorptiometry

$\mathrm{CHO}$ - Carbohydrate

$\dot{\mathrm{VCO}}_{2}$ - Production of carbon dioxide

IGF-1 - Insulin-like factor

$\mathrm{GH}$ - Growth hormone

$\mathrm{CIH}$ - Creatinine index - height

IFN-y - Interferon

NF-kB - Nuclear factor $\mathrm{kB}$

$\mathrm{PaO}_{2}$ - Partial oxygen pressure

REE - Resting energy expenditure

\section{INTRODUCTION}

Chronic obstructive pulmonary disease (COPD) is characterized by a not entirely

reversible limitation of the airflow. This airflow limitation is progressive and associated with an abnormal inflammatory response of the lung to gases and harmful particles ${ }^{(1)}$.

The clinical manifestations of COPD are not limited to pulmonary inflammation only. It is a disease that is actually associated with clinically significant systemic alterations (2). The systemic aspect includes oxydative stress and high levels of inflammatory mediators and acute-phase proteins. As in other inflammatory diseases, weight loss, muscular mass loss and tissue depletion are also seen in COPD.

* Work carried out at the University of Toronto, ON, Canada.

1. Doctor in Pneumology by Unifesp/EPM. Post-doctoral training at the University of Toronto. Specialist Title awarded by SBPT.

Mailing address - Ivone Martins Ferreira, 53 Abbott Ave., Toronto, ON, Canada, M6P 1H3. E-mail: ivoneferreira@hotmail.com

Received for publication on 12/10/02. Approved, after revision, on 02/05/03. 


\section{DIMENSIONS OF THE PROBLEM}

COPD is recognized all over the world as a public health problem. In the US alone, it already affects more than 17 million people and is responsible for the loss of more than half a million potential years of life (3). It accounts for an estimated direct annual cost of more than US\$ 18 million, besides its significantly negative impact on the population's work force. Due to its progressive and limiting nature, COPD interferes with the working performance, leading to a significant loss of productivity and income. A recent study used data from the Third National Health and Nutrition Research and estimated that, in 1994, COPD was responsible for the loss of at least US\$ 9.9 billion in the USA ${ }^{(3)}$.

In Brazil, the estimates are that at least 7.5 million people have COPD; although recent economic data are not available, the results are certainly not less devastating.

As opposed to cardiovascular diseases, for which the number of deaths has decreased over the last years, mortality due to COPD continues to grow. It is estimated that, by 2020, COPD will be worldwide the fifth largest cause of DALY (disability adjusted life year $=$ loss of years of life due to early mortality and years of living with the disease, adjusted for the severity of the disease). COPD will only be preceded by ischemic heart disease, depression, traffic accidents, and cardiovascular disease ${ }^{(1)}$.

Malnutrition has a rather negative impact on the clinical outcome of patients with COPD, since nutrition and ventilation are closely related. Oxygen and nutrients are necessary and participate together in the process of breathing and supplying energy for the daily life activities.

A significant number of patients with COPD present involuntary weight loss during the disease. The numbers range between $20-30 \%$ in stable patients and can reach $50 \%$ in hospitalized patients with respiratory failure $^{(4)}$.

\section{LOW BODY MASS INDEX (BMI) - CONSEQUENCE OR CAUSE?}

It is still uncertain whether weight loss is a consequence of the disease or actually a risk factor. For decades, it was thought that malnutrition was an inevitable consequence of the disease. More recently, there are studies suggesting that individuals which are susceptible to COPD seem to be thinner than the nonsusceptible.

An observational retrospective epidemiological study found that, in men, the risk of developing COPD varied inversely to their initial $\mathrm{BMI}$, even after correction for other factors, including smoking, age, $\mathrm{EFV}_{1}$, abdominal obesity, and level of education. However, this study has two major limitations: it is retrospective and did not include a sufficient number of women (5).

In animals, malnutrition has been associated with emphysematous alterations of the lung, possibly related to an antiprotease deficiency. Findings of emphysema, bronchiectasis and bullae in a young woman with anorexia nervosa ${ }^{(6)}$ raised the hypothesis of the socalled "nutritional emphysema". However, Pieters et al. rejected this hypothesis, based on their study of 24 women with anorexia nervosa, since their pulmonary function tests were normal. Diffusion capacity was normal, although lower in smokers. It is interesting to note that in this study the respiratory muscle pressures were rather compromised, with an IPmax at 59\% of the expected, and an EPmax at 35\% of the expected value, in addition to an increase of the residual volume $(160 \% \text { of the expected })^{(7)}$.

\section{CONSEQUENCES OF MALNUTRITION}

Several studies have demonstrated the association between malnutrition and functional damage in patients with $\operatorname{COPD}^{(8-12)}$. Various factors can contribute to the respiratory damage. Malnutrition damages the normal functioning of the skeletal muscles, whether there is a lung disease or not (8). Malnutrition reduces the diaphragmatic mass and contributes to the decreasing of strength and resistance of the respiratory muscles $(8,10)$. Consequently, patients who lose weight have more dyspnea, a higher degree of air trapping, and a greater limitation to exercise than those with a stable weight and the same degree of obstruction ${ }^{(13)}$. Furthermore, their diffusion capacity is usually more damaged ${ }^{(14)}$. As the muscle mass and function decrease, the muscles undergo a greater demand in order to keep up the ventilation work. Over time, the muscles become less efficient due to fatigue. Respiratory failure then becomes common, as the weight loss progresses.

These changes are not limited to the respiratory muscles only, since the other skeletal muscles are affected as well, determining a decrease in mobility and a higher risk of falling. Additionally, malnutrition is in direct correlation with osteoporosis $(15,16)$.

Malnutrition has also been associated with a higher susceptibility to infections, due in part to a decrease in cell immunity, a reduction of secretory IgA, a decrease in alveolar macrophage function, and a growth of bacterial colonization and adhesion in the upper and lower airways $(17)$.

The quality of life is definitely more affected in malnourished individuals (18), who also present a higher mortality rate than those with an adequate 
nutritional status ${ }^{(12)}$. Low body mass index and oxygen use were independent predictors of a reduction in the survival of hypoxic patients with COPD ${ }^{(9)}$.

\section{BODY COMPOSITION}

Patients are considered malnourished whenever their weight is $<90 \%$ of the ideal weight (19) or their weight/height ${ }^{2}$ ratio is less than $20 \mathrm{~kg} / \mathrm{m}^{2(20)}$.

Since weight and height per se do not discriminate fat from muscular mass or fat-free mass, it is important to evaluate the body composition by other methods, such as bio-impedance $(21,22)$ or DEXA (dual-energy Xray absorptiometry) $(23,24)$. There are studies showing that a reduction in fat-free mass may be present even in patients with normal weight ${ }^{(25)}$.

An evaluation of the body composition can bring additional benefits, for, by verifying where the loss is occurring, it is possible to get an idea about the pathogenesis of the weight loss. For example, a predominant loss of the fat deposit may represent an imbalance due to inadequate dietary intake examples: early satiety, dyspnea and fatigue; or an increased requirement, due to increased ventilation work (26).

High levels of cytokine have a major inflammatory effect on the fat-free mass, just like chronic hypoxia and the use of corticosteroids can influence the body composition. Unfortunately, many patients show up at an advanced stage of the disease, making a clinical differentiation of the etiology of weight loss very difficult.
Classical evidence about malnutrition being more common in patients with emphysema than in those with chronic bronchitis (11) were ratified by a recent study which included body composition measurements (27).

Patients with emphysema had a lower BMI, a lower fat-free mass index and a lower fat index than patients with bronchitis or normal individuals (27). Later on, the same authors showed that the total mass and the extremity fat-free mass were lower in patients with emphysema and with chronic bronchitis than in controls, but the central fat-free mass was lower only in those with emphysema. Extremity fat-free mass was lower in both groups than in controls, and the muscular function was comparable in both groups, showing that muscular weakness does not depend on the COPD subtype (28). This finding has a significant clinical implication, since the fat-free or muscular mass is definitely correlated with exercise performance in patients with COPD ${ }^{\text {(29-31) }}$.

Concerning fat, it is now known that it is not only an energy reservoir, but plays also a major role in homeostasis because it produces leptin. This hormone derived from fat cells seems to represent an afferent signal for the brain in the feedback mechanism that regulates fat mass. It plays a role in the metabolism of lipids, in glucose homeostasis, increases thermogenesis, and seems to have an effect on T-cellmediated immunity (32). Published data are few, but both Takabatake et al. (33) and Schols et al. ${ }^{(34)}$ found lower leptin levels in patients with COPD, without any correlation with tumor necrosis factor. 


\begin{tabular}{|c|c|c|c|c|}
\hline \multicolumn{5}{|c|}{$\begin{array}{c}\text { CHART } 1 \\
\text { Summary of randomized studies which examined the effects of nutritional supplementation during more than two weeks }\end{array}$} \\
\hline Studies & $\begin{array}{l}\text { Nutritional } \\
\text { status /location }\end{array}$ & $\begin{array}{l}\text { Via/quantity/ } \\
\text { duration }\end{array}$ & Results & $\begin{array}{l}\text { Quality } \\
\text { score }^{(69)}\end{array}$ \\
\hline Lewis et al.(70) 1987 & $\begin{array}{l}\text { Malnourished/ } \\
\text { outpatients } \\
\text { strength. }\end{array}$ & $\begin{array}{l}500-1,000 \mathrm{kcal} / \\
\text { day/oral } / 8 \text { weeks }\end{array}$ & $\begin{array}{l}\text { Non-significant dif. in weight, AMC, } \\
\text { tricipital fold, PFT, respiratory muscle }\end{array}$ & 1 \\
\hline Knowles et al.(71) 1988 & $\begin{array}{l}\text { Nourished and } \\
\text { malnourished/ } \\
\text { outpatients }\end{array}$ & $\begin{array}{l}18-26 \% \text { calories } \\
\text { increase/oral/ } \\
8 \text { weeks }\end{array}$ & $\begin{array}{l}\text { No alteration in AMC or tricipital fold, } \\
\text { weight gain, but return to baseline } \\
\text { when supplementation stopped. }\end{array}$ & 2 \\
\hline Efthimiou et al. (72) 1988 & $\begin{array}{l}\text { Malnourished/ } \\
\text { outpatients }\end{array}$ & $\begin{array}{l}640-1,280 \mathrm{kcal} / \mathrm{day} / \\
\text { oral/12 weeks }\end{array}$ & $\begin{array}{l}\text { Increase in weight, tricipital fold, } \\
\text { respiratory muscle strength and } \\
\text { well-being . } \\
\text { supplementation. }\end{array}$ & 11 \\
\hline $\begin{array}{l}\text { Whittaker et al.(73) } 1989 \\
\text { (Ryan et al. 1993)(74) }\end{array}$ & Malnourished/ & $\begin{array}{l}1,000 \mathrm{kcal} / \text { day/ } \\
16 \text { days }\end{array}$ & $\begin{array}{l}\text { Increase of EPmax, without alteration } \\
\text { Ryan: weight gain. - same study }\end{array}$ & 4 \\
\hline Otte et al. ${ }^{(75)} 1989$ & $\begin{array}{l}\text { Malnourished/ } \\
\text { outpatients }\end{array}$ & $\begin{array}{l}400 \mathrm{kcal} / \text { day/ } \\
\text { oral } / 13 \text { weeks }\end{array}$ & $\begin{array}{l}\text { Increase in weight and sum of skin } \\
\text { folds, no alteration in PFT, dyspnea } \\
\text { score or well-being. }\end{array}$ & 4 \\
\hline Fuenzalida et al.(76) 1990 & $\begin{array}{l}\text { Malnourished/ } \\
\text { hospitalized/ } \\
\text { followed-up }\end{array}$ & $\begin{array}{l}1,080 \mathrm{kcal} / \text { oral/ } \\
21 \mathrm{~d} \text { hospital/ } \\
21 \text { outpatients }\end{array}$ & $\begin{array}{l}\text { Increase in lymphocyte count, skin } \\
\text { reactivity, tricipital fold and AMC. } \\
\text { Weight gain occurred in both groups. }\end{array}$ & 11 \\
\hline $\begin{array}{l}\text { DeLetter (DeLetter, M.C. } \\
\text { data) } 1991\end{array}$ & $\begin{array}{l}\text { Malnourished/ } \\
\text { outpatients }\end{array}$ & $\begin{array}{l}1 \text { can }(355 \mathrm{kcal}) / \text { day/ } \\
\text { oral/ } 9 \text { weeks }\end{array}$ & $\begin{array}{l}\text { Increase in weight, tricipital fold and } \\
\text { fat. }\end{array}$ & $\begin{array}{l}\text { unpublished } \\
2\end{array}$ \\
\hline Rogers et al.(46) 1992* & $\begin{array}{l}\text { Malnourished/ } \\
\text { hospitalized }\end{array}$ & $\begin{array}{l}1.7 \mathrm{REE} \mathrm{kcal} / \mathrm{d} / \\
\text { oral/4 weeks }\end{array}$ & $\begin{array}{l}\text { Increase in weight, EPmax, handgrip } \\
\text { and walked distance. }\end{array}$ & 2 \\
\hline Vargas et al.(47) 1995* & $\begin{array}{l}\text { Nourished/ } \\
\text { outpatients }\end{array}$ & $\begin{array}{l}1,000 \mathrm{kcal} / \text { day/oral/ } \\
3 \text { months }+ \\
\text { LL training }\end{array}$ & $\begin{array}{l}\text { No alterations in anthropometry and } \\
\text { respiratory muscle strength. }\end{array}$ & 1 \\
\hline Schols et al.(45) 1995 & $\begin{array}{l}\text { Malnourished } \\
\text { and nourished/ } \\
\text { outpatients }\end{array}$ & $\begin{array}{l}420 \mathrm{kcal} / \mathrm{d} / \\
\text { oral } / 8 \text { weeks }\end{array}$ & $\begin{array}{l}\text { Increase in weight, fat-free mass, } \\
\text { IPmax, no alteration in distance } \\
\text { walked. }\end{array}$ & 2 \\
\hline
\end{tabular}

$\mathrm{PFT}=$ pulmonary function test, $\mathrm{AMC}=$ arm muscle circumference, ${ }^{*}=$ not included in meta-analysis.

\section{STUDIES IN NUTRITIONAL SUPPLEMENTATION}

Considering that the presence of malnutrition is a clear disadvantage for patients with COPD, nutritional support has been suggested as a part of the treatment. Although some studies have shown an improvement in respiratory and muscular function, these findings are not the rule. An extensive review was recently carried out to answer the question whether nutritional support improves anthropometrical measurements, pulmonary function, respiratory and peripheral muscular function, exercise performance, and the quality of life (35). Randomized studies published in several languages were spotted by means of all possible sources, including Medline (since 1966), Embase, Cinahl (since 1982) and the Cochrane Airways Registry. In addition to that, works presented at international conferences held in North America and Europe were included, and experts in the field of nutrition were contacted all over the world, in order to locate still unpublished works or to obtain more detailed information about published works. A total number of 272 abstracts were found and, after an evaluation by two reviewers, this number was reduced to 55 publications $(k=0.89$; IC 95\% 0.82-0.96). After a careful review, 21 studies were included.

Four publications studied the immediate effects of food with different proportions of carbohydrates $(\mathrm{CHO})$ 
or fat on metabolism and on exercise performance (3639). Generally, a high carbohydrate diet resulted in an increase of the respiratory quotient and of the carbon dioxide production $\left(\dot{\mathrm{V}} \mathrm{CO}_{2}\right)$, with the consequent reduction of exercise performance. The increase of ventilation requirement was larger following $\mathrm{CHO}$ intake than fat intake. These studies had results similar to other three which investigated the effects of shortterm supplementation $\left(<\right.$ two weeks) ${ }^{(40-42)}$. The $\dot{\mathrm{VCO}}_{2}$ increase can worsen the condition of patients in respiratory failure, but its effect on stable patients is small, of little clinical importance. It is important to point out that a more recently published study did not find any difference in exercise performance and that, although high dietary carbohydrate did determine an increase in the respiratory quotient, dyspnea was significantly higher when the patients received a highfat diet (43).

Highly significant are the studies on nutritional supplementation for over two weeks. A total of 10 publications verified the effects of nutritional supplementation in COPD. The 10 randomized studies are summarized in Table 1.

Only eight publications could be included in the meta-analysis, because important data were not obtained from the authors ${ }^{(44)}$. One of the included works (45) was analyzed as two publications, since it studied both nourished and malnourished patients. The two works which were excluded from the metaanalysis would not change the results obtained, because the result of one of them was positive, and the result of the other was negative $(46,47)$. No significant randomized study was published after this review.

On meta-analysis, the effects of nutritional supplementation on weight, arm muscle circumference, triceps, six-minute walking, $\mathrm{VEF}_{1}$, IPmax and EPmax (48) were verified. The effect of the treatment was extremely small, its values not reaching clinical relevance. The 95\% confidence interval for all variables included zero. The effect was homogeneous for all variables measured, showing that the result of the nutritional intervention was consistent across the studies, regardless of their duration and of the amount supplemented (48). Unfortunately, in most of the studies, data on the evaluation of fat-free muscular mass and quality of life were not analyzed and could not be included in the meta-analysis. These variables are undoubtedly very important and should be included in future investigations on this matter.

These results are probably disappointing for physicians who are in direct contact with the patients and are certainly able to appreciate the benefits and the joy caused by weight gain. It seems to be clear that, when a patient responds to nutritional treatment, his/her prognosis improves. It may be our task to identify those patients who will respond to this therapy.

\section{STUDIES ON ANABOLIC STEROIDS AND GROWTH HORMONE}

Only two randomized studies were published evaluating the effects of anabolic steroids in association with a pulmonary rehabilitation program. In the study published by Schols et al., the weight gain was similar in the group that received nutritional support and in the group that received nutritional support and anabolic steroids, the weight gain having been greater in malnourished patients. The patients who received combined treatment gained more fat-free mass, whereas those who received only nutritional support gained more fat. The increase in respiratory muscle strength was significant in the group with combined therapy, but showed no difference regarding the group that had received only nutritional support ${ }^{(45)}$.

In a study carried out in Brazil on malnourished patients with low respiratory muscle strength, those who received an anabolic steroid during 27 weeks gained weight and had their fat-free muscular mass increased as compared to those receiving placebo, measured both by the arm muscle circumference and by DEXA. The strength increase of the respiratory muscles was significant in both groups, without any difference between them ${ }^{(23)}$.

Studies with growth hormone have been disappointing; only one randomized study was published which certainly showed an increase in fatfree mass, but without any effect on the respiratory muscles or on exercise performance ${ }^{(49)}$. Moreover, it is more likely to cause side effects and is available only as injections. A multicentric study with IGF-1-derived substances is under way in Canada and seems to be promising.

\section{THE MECHANISM OF WEIGHT LOSS AND MUSCULAR DEPLETION}

It is probable that weight loss in COPD results both from a failure in the adaptive response to malnutrition and from a dietary intake that is inadequate for a certain requirement. However, in the studies on nutritional supplementation for over two weeks, the amount of ingested calories seems to have been adequate, as estimated by the Moore-Angelilo equation (35).

Other explanations include hypermetabolism (50), diet-induced thermogenesis, tissue hypoxia (51), and the use of corticosteroids ${ }^{(52)}$. It may also be related to 
an imbalance between protein breakdown and replacement, as well as to alterations in the level of hormones, such as insulin, growth hormone, testosterone, and glucocorticoids.

Hormone alterations are closely related to protein turnover. Insulin, growth hormone $(\mathrm{GH})$, insulin-like factor (IGFs), and anabolic hormones promote protein synthesis, while glucocorticoids favor proteinolysis, especially in muscular tissue. In the absence of fasting, insulin normally suppresses protein breakdown. GH also increases fat-free mass and produces a positive nitrogen balance, besides the breakdown of fat mass. There is some evidence suggesting that there may be resistance to $\mathrm{GH}$ in catabolism conditions, as they occur in inflammations. Fasting and a state of catabolism are associated with a decrease in $\mathrm{GH}$ receptor, in IGF-1 gene expression, and a low level of IGF-1-binding protein (2).

In animals, infusion of interleukin-1 and TNF-alpha results in a decrease of IGF-1 levels, and protein synthesis and the protein-stimulating capacity of IGF-1 are inhibited when myoblasts are exposed to TNFalpha(2).

Some studies have suggested that there may be a relationship between weight loss and a contribution of the systemic response similar to the cachexia syndrome found in cardiac failure and cystic fibrosis.

Several studies have shown high tumor necrosis factor (TNF) levels in patients with COPD $^{(53-55)}$. The levels of circulating TNF-alpha, interleukin-6, and soluble receptors were significantly higher in patients with COPD with BMI below $20 \mathrm{~kg} / \mathrm{m}^{2}$ or a low creatinine index $-\mathrm{CHI}(<80 \%$ of the expected) than in patients with normal $\mathrm{BMI}$ and $\mathrm{CHI}$ (56).

In their study on the direct effects of TNF-alpha on differentiated skeletal cells, $\mathrm{Li}$ and Reid demonstrated the occurrence of a reduction of the total protein content and a loss of the adult heavy myosine chain (57). These alterations were evident in concentrations similar to those found in COPD.

Chronic hypoxia might also foster weight loss because it increases the production of cytokines. Hypoxia increases the release of interleukin-1 and TNF-alpha in human alveolar macrophages studied in vitro. This suggests that the inflammatory process can be stimulated or worsened by the tissue hypoxia that is common in severe emphysema.

The findings of Pitsiou et al. are in accordance with this hypothesis. These authors compared the TNF factors of predominantly emphysematous (pink puffers) and predominantly bronchitis (blue boaters) patients, and found a TNF in the first group that was twice as high as the one of the second group. The emphysema group also presented higher tissue hypoxia, lower diffusion capacity, the patients were significantly hypermetabolic as compared to those with bronchitis and had a significantly lower BMI (58).

Some studies suggest that TNF-alpha and interferon IFN-y affect muscular regulation during two phases: by inhibiting the formation of new myofibers and leading to the degeneration of newly formed myotubules, and by the inability to repair the damaged skeletal musculature (2). Another study, carried out by Reid et al., demonstrated that TNF-alpha also compromises similarly the contractile function of both the diaphragm and the limbs. This probably occurs because it blocks the response of the muscle myofilament to calcium action (59).

There is also another hypothesis according to which inflammatory cytokines could contribute to muscular decay by inhibiting myogenic differentiation through nuclear factor $k B(N F-k B)(60,61)$.

To make things even more complicated, chronic use of corticosteroids to treat COPD is associated with weakness and loss of muscle mass. Glucocorticoids stimulate proteinolysis and inhibit protein synthesis and amino acid transport into the muscle cells.

Another pathway that may contribute to muscle mass reduction is apoptosis or programmed cell death, since chronic inflammation can be a major trigger of muscle decay. In a recent study, it was found that the number of apoptotic cells in biopsies increased progressively when comparing normal active subjects, normal inactive subjects, COPD patients with normal body mass, and COPD patients with low BMI. There was also an inverse correlation between body mass index and degree of apoptosis (62). These are extremely exciting findings, but unfortunately the authors used only BMI, without a direct evaluation of the body composition. In addition to that, the control group was younger than the COPD group, which might have influenced the results ${ }^{(63)}$. At any rate, this is a very interesting matter, that has only recently begun to be investigated and deserves more in-depth study.

\section{POSSIBLE MECHANISMS INVOLVED IN THE}

\section{ABSENCE OF RESPONSE TO NUTRITIONAL}

\section{THERAPY}

Understanding the factors which determine the response to nutritional therapy is fundamental, since the response is a critical indicator. Mortality is lower in patients which respond to treatment than in nonresponsive patients $(64)$.

Schols et al. studied the prognostic implications of body weight in COPD and constructed two survival curves. The first one was a retrospective study of 400 patients who underwent rehabilitation without nutritional supplementation. Similarly to other studies, 
the authors found that low $\mathrm{BMI}$, age, and $\mathrm{PaO}_{2}$ were independent mortality-predictive factors. When BMI was below $25 \mathrm{~kg} / \mathrm{m}^{2}$, mortality was increased. The second survival curve was a post hoc analysis of the prospective study in which the patients received nutrition or an anabolic steroid. In these subjects, a weight gain of more than 2 kilograms in eight weeks, in both malnourished and not malnourished patients, as well as an increase in IPmax, were significant predictive factors of survival ${ }^{(64)}$.

The problem we face then is to definitely identify a treatment capable of exerting a positive influence on fat-free mass (muscle).

In order to determine the factors which are related with or predictive of the response to nutritional therapy, Creutzberg et al. studied a group of patients submitted to rehabilitation. REE, pulmonary function, cytokine levels, systemic inflammation markers and body composition were measured. The patients received 500 to 750 additional calories during eight weeks and, at the end of this period of time, the authors divided them into groups, based on their weight gain. Nineteen out of 24 patients presented a $2 \%$ response, and in 15 patients the weight gain was $5 \%$ or more. Using linear regression analysis, it was shown that absence of response to therapy was associated with old age, relative anorexia, and high systemic inflammatory response (65).

In patients with pulmonary cachexia, a possible cytokine-leptin bond may be related to poor response to nutritional support. These studies suggest that response to nutritional supplementation is related to the degree of inflammation, and that measuring its markers may be useful to determine prognosis and response to therapy.

\section{WHAT CAN BE DONE TO SOLVE THE PROBLEM? DIRECTIONS FOR THE FUTURE}

Nutritional supplementation is feasible, mainly in patients involved in rehabilitation, in which caloric intake can be controlled. It is also possible to promote weight gain through participation in an exercise program, especially when training of the extremity musculature is included. Nutritional support alone may not be sufficient to promote a substantial weight and muscle mass gain, as opposed to fat gain (44).

In a recent study, megestrol acetate, an appetitestimulating progestin-derived substance, was effective in stimulating weight gain, but, once again, weight gain occurred as fat gain. There was no improvement in respiratory muscle strength nor in the six-minuteswalking distance, which actually decreased in the treated group, as did the serum testosterone levels ${ }^{(66)}$.
It is however always interesting to be able to consider appetite stimulators as another treatment option.

Anabolic steroids can be useful in certain cases, by their influence on the anabolic protein receptors and the inhibition of catabolism by glucocorticoids. They may prove useful especially in subjects with decreased testosterone levels, which frequently occur in chronic diseases like COPD.

There are studies showing that COPD is characterized by complex metabolic disorders. Further studies are necessary to clarify the complexity of metabolic alterations related to inflammation, hypoxia, hypercapnia, and energy depletion.

Different factors may be contributing to the muscle alteration in COPD, and the relative participation of each factor may be different in each patient, as well as in different types of muscles. Given the importance of the muscular function with regard to morbidity and quality of life, treatment should probably be based on a more adequate characterization of each patient. This characterization must include at least, besides BMI, an evaluation of body composition and skeletal and respiratory muscular function. It is possible that nutritional therapy should be more individualized and targeted on the causal factors.

In the future, cytokines or cytokine inhibitors may become more advantageous than corticosteroids in the treatment of $\mathrm{COPD}^{(67)}$. Perhaps novel therapies will include anti-TNF antibodies, similarly to studies on chronic colitis and rheumatoid arthritis, where the treatment has produced a significant response regarding the reduction of inflammation and symptoms, and an improvement in the quality of life, even in patients who are non-responsive to corticosteroids $^{(68)}$.

Another possibility would be the use of antiinflammatory cytokines such as IL-10, since it is a TNFalpha and chemokine inhibitor, as well as of certain metaproteinases such as MM-9, that may be involved in the destruction of pulmonary parenchyma elastin. Currently, however, it is available only as injections and has undesirable hematological effects (68).

It is further possible that direct inhibition of NF-kB through novel therapies may reduce the muscular depletion associated with cachexia ${ }^{(2)}$.

Summing it all up, there is hope that novel therapies will help us win this battle.

\section{ACKNOWLEDGMENTS}

I thank Doctors Andrea D. Furlan and Carlos Alberto de Castro Pereira for reviewing the manuscript. 


\section{REFERENCES}

1. Pauwels RA, Buist AS, Calverley PM, Jenkins, Hurd SS. Global strategy for the diagnosis, management, and prevention of chronic obstructive pulmonary disease. NHLBI/WHO Global Initiative for Chronic Obstructive Lung Disease (GOLD) Workshop summary. Am J Respir Crit Care Med 2001;163:1256-76.

2. Wouters EF, Creutzberg EC, Schols AM. Systemic effects in COPD. Chest 2002;121:127S-30S.

3. Sin DD, Stafinski T, Ng YC, Bell NR, Jacobs P. The impact of chronic obstructive pulmonary disease on work loss in the United States. Am J Respir Crit Care Med 2002; 165:704-7.

4. Donahoe M, Rogers RM. Nutritional assessment and support in chronic obstructive pulmonary disease. Clin Chest Med 1990;11:487-504.

5. Harik-Khan RI, Fleg JL, Wise RA. Body mass index and the risk of COPD. Chest 2002;121:370-6.

6. Cook VJ, Coxson HO, Mason AG, Bai TR. Bullae, bronchiectasis and nutritional emphysema in severe anorexia nervosa. Can Respir J 2001; 8:361-5.

7. Pieters T, Boland B, Beguin C, Veriter C, Stanescu D, Frans $A$, et al. Lung function study and diffusion capacity in anorexia nervosa. J Intern Med 2000;248:137-42.

8. Arora NS, Rochester DF. Respiratory muscle strength and maximal voluntary ventilation in undernourished patients. Am Rev Respir Dis 1982;126:5-8.

9. Gray-Donald K, Gibbons L, Shapiro SH, Macklem PT, Martin JG. Nutritional status and mortality in chronic obstructive pulmonary disease. Am J Respir Crit Care Med 1996;153:961-6.

10. Lewis MI, Belman MJ. Nutrition and the respiratory muscles. Clin Chest Med 1988;9:337-48.

11. Openbrier DR, Irwin MM, Rogers RM, Gottlieb GP, Dauber JH, Van Thiel DH, et al. Nutritional status and lung function in patients with emphysema and chronic bronchitis. Chest 1983;83:17-22.

12. Wilson DO, Rogers RM, Wright EC, Anthonisen NR. Body weight in chronic obstructive pulmonary disease. The National Institutes of Health Intermittent PositivePressure Breathing Trial. Am Rev Respir Dis 1989; 139:1435-8.

13. Sahebjami H, Doers JT, Render ML, Bond TL. Anthropometric and pulmonary function test profiles of outpatients with stable chronic obstructive pulmonary disease. Am J Med 1993;94:469-74.

14. Sahebjami H, Sathianpitayakul E. Influence of body weight on the severity of dyspnea in chronic obstructive pulmonary disease. Am J Respir Crit Care Med 2000;161:886-90.

15. Incalzi RA, Caradonna P, Ranieri P, Basso S, Fuso L, Pagano F, et al. Correlates of osteoporosis in chronic obstructive pulmonary disease. Respir Med 2000;94:1079-84.

16. Biskobing DM. COPD and osteoporosis. Chest 2002;121:609-20.

17. Lewis MI. Nutrition and chronic obstructive disease: a clinical overview. In: Bach JR, editor. Pulmonary rehabilitation: the obstructive and paralytic condition. Philadelphia, P.A.: Henley \& Belfus/Mosby, 1996;15771.

18. Mostert R, Goris A, Weling-Scheepers C, Wouters EF, Schols AM. Tissue depletion and health related quality of life in patients with chronic obstructive pulmonary disease. Respir Med 2000;94:859-67.

19. Metropolitan Life Insurance Company. New weight standards for men and women. Stat Bull Metrop Life Found 1983;64:1-4.

20. World Health Organization. Diet, nutrition and prevention of chronic disease. Geneva; 1990. (Technical report series, n. 797, p. 69-74.

21. Baarends EM, Marken Lichtenbelt WD, Wouters EF, Schols AM. Body-water compartments measured by bioelectrical impedance spectroscopy in patients with chronic obstructive pulmonary disease. Clin Nutr 1998; 17:15-22.

22. Schols AM, Wouters EF, Soeters PB, Westerterp KR. Body composition by bioelectrical-impedance analysis compared with deuterium dilution and skinfold anthropometry in patients with chronic obstructive pulmonary disease. Am J Clin Nutr 1991;53:421-4.

23. Ferreira IM, Verreschi IT, Nery LE, Goldstein RS, Zamel $\mathrm{N}$, Brooks $\mathrm{D}$, et al. The influence of 6 months of oral anabolic steroids on body mass and respiratory muscles in undernourished COPD patients. Chest 1998; 114:19-28.

24. Engelen MP, Schols AM, Heidendal GA, Wouters EF. Dual-energy X-ray absorptiometry in the clinical evaluation of body composition and bone mineral density in patients with chronic obstructive pulmonary disease. Am J Clin Nutr 1998;68:1298-303.

25. Schols AM, Soeters PB, Dingemans AM, Mostert R, Frantzen PJ, Wouters EF. Prevalence and characteristics of nutritional depletion in patients with stable COPD eligible for pulmonary rehabilitation. Am Rev Respir Dis 1993;147:1151-6.

26. Berry JK, Baum CL. Malnutrition in chronic obstructive pulmonary disease: adding insult to injury. AACN Clin Issues 2001;12:210-9.

27. Engelen MP, Schols AM, Lamers RJ, Wouters EF. Different patterns of chronic tissue wasting among patients with chronic obstructive pulmonary disease. Clin Nutr 1999;18:275-80.

28. Engelen MP, Schols AM, Does JD, Wouters EF. Skeletal muscle weakness is associated with wasting of extremity fat-free mass but not with airflow obstruction in patients with chronic obstructive pulmonary disease. Am J Clin Nutr 2000;71:733-8.

29. Schols AM, Mostert R, Soeters PB, Wouters EF. Body composition and exercise performance in patients with chronic obstructive pulmonary disease. Thorax 1991;46:695-9.

30. Palange P, Forte S, Felli A, Carlone S. Nutritional status and exercise performance in chronic obstructive pulmonary disease (COPD). Monaldi Arch Chest Dis 1993;48:543-5. 
31. Palange $\mathrm{P}$, Forte $\mathrm{S}$, Felli $\mathrm{A}$, Galassetti $\mathrm{P}$, Serra $\mathrm{P}$, Carlone S. Nutritional state and exercise tolerance in patients with COPD. Chest 1995; 107:1206-12.

32. Wouters EF. Nutrition and metabolism in COPD. Chest 2000;117: 274S-80S.

33. Takabatake $\mathrm{N}$, Nakamura $\mathrm{H}$, Abe $\mathrm{S}$, Hino $\mathrm{T}$, Saito $\mathrm{H}$, Yuki $\mathrm{H}$, et al. Circulating leptin in patients with chronic obstructive pulmonary disease. Am J Respir Crit Care Med 1999;159:1215-9.

34. Schols AM, Creutzberg EC, Buurman WA, Campfield LA, Saris WH, Wouters EF. Plasma leptin is related to proinflammatory status and dietary intake in patients with chronic obstructive pulmonary disease. Am J Respir Crit Care Med 1999;160:1220-6.

35. Ferreira I, Brooks D, Lacasse Y, Goldstein R. Nutritional intervention in COPD: a systematic overview. Chest 2001;119:353-63.

36. Brown SE, Nagendran RC, McHugh JW, Stansbury DW, Fischer CE, Light RW. Effects of a large carbohydrate load on walking performance in chronic air-flow obstruction. Am Rev Respir Dis 1985;132:960-2.

37. Efthimiou J, Mounsey PJ, Benson DN, Madgwick R, Coles SJ, Benson MK. Effect of carbohydrate rich versus fat rich loads on gas exchange and walking performance in patients with chronic obstructive lung disease. Thorax 1992;47:451-6.

38. Akrabawi SS, Mobarhan S, Stoltz RR, Ferguson PW. Gastric emptying, pulmonary function, gas exchange, and respiratory quotient after feeding a moderate versus high fat enteral formula meal in chronic obstructive pulmonary disease patients. Nutrition 1996;12:260-5.

39. Frankfort JD, Fischer CE, Stansbury DW, McArthur DL, Brown SE, Light RW. Effects of high and low carbohydrate meals on maximum exercise performance in chronic airflow obstruction. Chest 1991;100: 792-5.

40. Goldstein SA, Thomashow BM, Kvetan V, Askanazi J, Kinney JM, Elwyn DH. Nitrogen and energy relationships in malnourished patients with emphysema. Am Rev Respir Dis 1988;138:636-44.

41. Goldstein SA, Askanazi J, Elwyn DH, Thomashow B, Milic-Emili J, Kvetan V, et al. Submaximal exercise in emphysema and malnutrition at two levels of carbohydrate and fat intake. J Appl Physiol 1989;67: 1048-55.

42. Angelillo VA, Bedi S, Durfee D. Effects of low and high carbohydrate feeding in ambulatory patients with chronic obstructive pulmonary disease and hypercapnia. Ann Intern Med 1985;103:883-5.

43. Vermeeren MA, Wouters EF, Nelissen LH, Van Lier A, Hofman Z, Schols AM. Acute effects of different nutritional supplements on symptoms and functional capacity in patients with chronic obstructive pulmonary disease. Am J Clin Nutr 2001;73:295-301.

44. Ferreira IM, Brooks D, Lacasse Y, Goldstein RS. Nutritional support for individuals with COPD: a metaanalysis. Chest 2000;117:672-8.

45. Schols AM, Soeters PB, Mostert R, Pluymers RJ, Wouters EF. Physiologic effects of nutritional support and anabolic steroids in patients with chronic obstructive pulmonary disease. A placebo-controlled randomized trial. Am J Respir Crit Care Med 1995;152:1268-74.

46. Rogers RM, Donahoe M, Costantino J. Physiologic effects of oral supplemental feeding in malnourished patients with chronic obstructive pulmonary disease. A randomized control study. Am Rev Respir Dis 1992; 146: 1511-7.

47. Vargas MD, Puig A, Pia de La Mazza C. Pacientes con limitacion cronica al flujo aereo: efectos del entrenamiento muscular respiratorio con valvula de carga umral construida con tecnologia apropiada, asociada a apoyo nutricional. Rev Med Chil 1995; $123: 1225-34$.

48. Ferreira IM, Brooks D, Lacasse Y, Goldstein S. Nutritional supplementation in stable chronic obstructive pulmonary disease. Cochrane Database Syst Rev 2000. CD000998.

49. Burdet L, Muralt B, Schutz Y, Pichard C, Fitting JW. Administration of growth hormone to underweight patients with chronic obstructive pulmonary disease. A prospective, randomized, controlled study. Am J Respir Crit Care Med 1997;156:1800-6.

50. Schols AM. TNF-alpha and hypermetabolism in chronic obstructive pulmonary disease. Clin Nutr 1999;18:2557.

51. Donahoe M, Rogers RM, Cottrell JJ. Is loss of body weight in chronic obstructive pulmonary disease patients with emphysema secondary to low tissue oxygenation? Respiration 1992;59(Suppl 2):33-9.

52. Donahoe M, Rogers RM. Mechanisms of weight loss in chronic obstructive pulmonary disease. Monaldi Arch Chest Dis 1993;48:522-9.

53. Di Francia M, Barbier D, Mege JL, Orehek J. Tumor necrosis factor-alpha levels and weight loss in chronic obstructive pulmonary disease. Am J Respir Crit Care Med 1994;150:1453-5.

54. de Godoy I, Donahoe M, Calhoun WJ, Mancino J, Rogers RM. Elevated TNF-alpha production by peripheral blood monocytes of weight- losing COPD patients. Am J Respir Crit Care Med 1996;153:633-7.

55. Schols AM, Buurman WA, Staal Van Den Brekel AJ, Dentener MA, Wouters EF. Evidence for a relation between metabolic derangements and increased levels of inflammatory mediators in a subgroup of patients with chronic obstructive pulmonary disease. Thorax 1996;51: 819-24.

56. Eid AA, Lonescu AA, Nixon LS, Lewis-Jenkins V, Matthews SB, Griffiths TL, et al. Inflammatory response and body composition in chronic obstructive pulmonary disease. Am J Respir Crit Care Med 2001; 164:1414-8.

57. Li YP, Reid MB. Effect of tumor necrosis factor-alpha on skeletal muscle metabolism. Curr Opin Rheumatol 2001;13:483-7.

58. Pitsiou G, Kyriazis G, Hatzizisi O, Argyropoulou P, Mavrofridis E, Patakas D. Tumor necrosis factor-alpha serum levels, weight loss and tissue oxygenation in chronic obstructive pulmonary disease. Respir Med 2002;96:594-8.

59. Reid MB, Lannergren J, Westerblad H. Respiratory and limb muscle weakness induced by tumor necrosis factor- 
alpha: involvement of muscle myofilaments. Am J Respir Crit Care Med 2002;166:479-84.

60. Langen RC, Schols AM, Kelders MC, Wouters EF, Janssen-Heininger YM. Inflammatory cytokines inhibit myogenic differentiation through activation of nuclear factor-kappaB. FASEB J 2001;15:1169-80.

61. Langen RC, Schols AM, Kelders MC, Van Der Velden JL, Wouters EF, Janssen-Heininger YM. Tumor necrosis factor-alpha inhibits myogenesis through redoxdependent and -independent pathways. Am J Physiol Cell Physiol 2002;283:C714-C21.

62. Agusti AG, Sauleda J, Miralles C, Gomez C, Togores B, Sala E, et al. Skeletal muscle apoptosis and weight loss in chronic obstructive pulmonary disease. Am J Respir Crit Care Med 2002;166:485-9.

63. Lewis MI. Apoptosis as a potential mechanism of muscle cachexia in chronic obstructive pulmonary disease. Am J Respir Crit Care Med 2002;166:434-6.

64. Schols AM, Slangen J, Volovics L, Wouters EF. Weight loss is a reversible factor in the prognosis of chronic obstructive pulmonary disease. Am J Respir Crit Care Med 1998;157:1791-7.

65. Creutzberg EC, Schols AM, Weling-Scheepers CA, Buurman WA, Wouters EF. Characterization of nonresponse to high caloric oral nutritional therapy in depleted patients with chronic obstructive pulmonary disease. Am J Respir Crit Care Med 2000;161:745-52.

66. Weisberg J, Wanger J, Olson J, Streit B, Fogarty C, Martin T, Casaburi R. Megestrol acetate stimulates weight gain and ventilation in underweight COPD patients. Chest 2002;121:1070-8.

67. De Boer WI. Cytokines and therapy in COPD: a promising combination? Chest 2002;121:209S-18S.
68. Barnes PJ. Cytokine modulators as novel therapies for airway disease. Eur Respir J 2001;18:67s-77s.

69. Jadad AR, Moore RA, Carroll D, Jenkinson C, Reynolds DJ, Gavaghan DJ, et al. Assessing the quality of reports of randomized clinical trials: is blinding necessary? Control Clin Trials 1996;17:1-12.

70. Lewis, MI, Belman MJ, Dorr-Uyemura L. Nutritional supplementation in ambulatory patients with chronic obstructive pulmonary disease. Am Rev Respir Dis 1987; 135: 1062-8.

71. Knowles JB, Fairbarn MS, Wiggs BJ, Chan-Yan C, Pardy RL. Dietary supplementation and respiratory muscle performance in patients with COPD. Chest 1988;93:977-83.

72. Efthimiou J, Fleming J, Gomes C, Spiro SG. The effect of supplementary oral nutrition in poorly nourished patients with chronic obstructive pulmonary disease. Am Rev Respir Dis 1988;137:1075-82.

73. Whittaker JS, Ryan CF, Buckley PA, Road JD. The effects of refeeding on peripheral and respiratory muscle function in malnourished chronic obstructive pulmonary disease patients. Am Rev Respir Dis 1990;142: 283-8.

74. Ryan CF, Road JD, Buckley PA, Ross C, Whittaker JS. Energy balance in stable malnourished patients with chronic obstructive pulmonary disease. Chest 1993;103:1038-44.

75. Otte KE, Ahlburg P, D'Amore F, Stellfeld M. Nutritional repletion in malnourished patients with emphysema. JPEN J Parenter Enteral Nutr 1989;13:152-6.

76. Fuenzalida CE, Petty TL, Jones ML, Jarrett S, Harbeck RJ, Terry RW, Hambidge KM. The immune response to short-term nutritional intervention in advanced chronic obstructive pulmonary disease. Am Rev Respir Dis 1990;142:49-56. 